Review Article

\title{
Effect of add-on proton pump inhibitors on parameters of glycemic control in type- 2 diabetic patients
}

\author{
Amruta P. Patil*, Prashant A. Shirure
}

Department of Pharmacology, Dr. Vaishampayan Memorial Government Medical College, Solapur 413003, Maharashtra, India

Received: 17 March 2017 Accepted: 22 April 2017

\section{*Correspondence to: Dr. Amruta P. Patil, Email: the.amrutapatil@ gmail.com}

Copyright: (C) the author(s), publisher and licensee Medip Academy. This is an openaccess article distributed under the terms of the Creative Commons Attribution NonCommercial License, which permits unrestricted noncommercial use, distribution, and reproduction in any medium, provided the original work is properly cited.

\begin{abstract}
Proton pump inhibitors (PPIs) block the parietal cell $\mathrm{H}+/ \mathrm{K}+$ ATPase, are superior at suppressing acid secretion \& promoting peptic ulcer healing, wildly used clinically for the therapy of gastro-esophageal reflex disease, gastritis due to excess stomach acid, and gastric ulcers. After blocking the production of gastric acid, the proton-pump inhibitors indirectly elevate serum gastrin levels via a negative feedback effect. Evidences are reported that gastrin promotes $\beta$ cell neogenesis in pancreatic ductal complex, modest pancreatic $\beta$ cell replication and improvement of glucose tolerance in animal models. Some recent clinical studies have shown improved glucose tolerance in type-2 diabetes mellitus (T2DM). Although PPIs may be possible candidates for a new approach in the therapy of diabetes, a prospective, long-term, randomized, double-blind, placebo-controlled study is needed to establish the effect of PPIs on glycemic control in a large number of patients with T2DM.
\end{abstract}

Keywords: $\beta$ cell neogenesis, Proton pump inhibitors, Raised gastrin level, Type 2 diabetes mellitus

\section{INTRODUCTION}

Type 2 diabetes mellitus is a heterogeneous and polygenic metabolic disease. ${ }^{1}$ The prevalence of diabetes is apidly rising all over the globe at an alarming rate. ${ }^{2}$ The pathogenic mechanisms of this disease are attributed to two key factors: dysfunction of pancreatic b-cells and insulin resistance in target tissues. Recent studies have suggested that age-dependent deterioration of type 2 diabetes is associated with progressive loss of b-cell function, which could be at least partly explained by loss of functional b-cell mass. ${ }^{1}$ At present the treatment of DM includes Insulin, biguanides, $\alpha$ glucosidase inhibitors, dipeptidyl peptidase IV inhibitors, sulfonylureas and thiazolidinediones, GLP-1 receptor agonists, Amylin agonists, medical nutrition therapy and life style modifications which lower glycaemia by various mechanisms. ${ }^{2}$ Most medications being used to treat type 2 diabetes cannot prevent $\beta$-cell death or reestablish $\beta$-cell mass. ${ }^{2}$

There is a high prevalence of upper gastrointestinal (GI) diseases in diabetes mellitus (DM), including gastro oesophageal reflux disease (GERD) and Acid peptic disease (APD). ${ }^{2}$

Over the past few decades, various therapeutic options have been proposed to maintain b-cell function and mass. ${ }^{1}$ Among those therapeutic options, glucagon-like peptide 1 (GLP-1) and its mimetic compound, exendin-4, gastrin, epidermal growth factor, transforming growth factor a new classes of diabetic agents, exert their 
functions through multiple pathways, acting on the brain to induce satiety, inhibiting gastric emptying and glucagon secretion, and potentiating glucose-stimulated insulin secretion, all together leading to improved glucose homeostasis. ${ }^{1,3}$

\section{GASTRIN PHYSIOLOGY AND ANIMAL STUDIES FOR EFFECT OF GASTRIN ON B CELL}

Gastrin is one of neurohormonal secretagogues, peptide hormone produced mainly in the $\mathrm{G}$ cells of the pyloric antrum of the stomach. ${ }^{4}$ The main role of gastrin is the promotion of gastric acid secretion from the parietal cells of the stomach. Gastrin can also act as a growth factor and stimulate gastric cell proliferation. ${ }^{5,6}$

The secretion of gastrin is stimulated by various factors, such as considerable distension of the stomach, vagal stimulation, the presence of food (especially protein, peptides, and amino acids) in the stomach and high $\mathrm{pH}$ levels in the stomach cavity (Figure 1). ${ }^{5,7}$

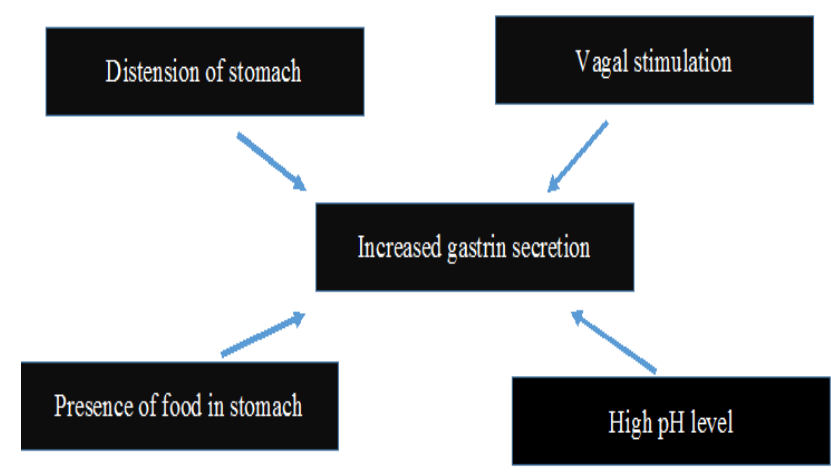

Figure 1: Factors stimulating gastrin secretion.

The main role of this hormone is the stimulation of secretion of gastric acid from the stomach parietal cells. The gastrin receptor, cholecystokinin B (CCK-B) receptor, binds to gastrin and to cholecystokinin with a similar high affinity. ${ }^{8}$ However, the expression of this receptor is also found on enterochromaffin-like (ECL) cells, and the binding of CCK-B receptor to gastrin on these cells promotes the secretion of the histamine resulting in subsequent promotion of the release of gastric acids by parietal cells, which may be the central mechanism of gastrin-stimulated acid secretion. ${ }^{8,9}$

CCK-B receptor/gastrin receptor is involved in glucose homeostasis in adult humans and mediates the autocrine effects of gastrin on islet differentiation and growth in the fetal pancreas. ${ }^{10}$

It is reported that gastrin promotes $\beta$ cell neogenesis in pancreatic ductal complex, modest pancreatic $\beta$ cell replication and improvement of glucose tolerance in animal models in which the remodeling of pancreatic tissues is promoted..$^{8,10-14}$
Nevertheless, resection of the gastric antrum as part of Whipple's operation that reduced serum gastrin levels to very low or undetectable levels was not associated with any diminution of the incretin effect, suggesting that whatever role gastrin played was dispensable, at least in non-diabetic individuals. ${ }^{14}$

A report suggesting that, in $95 \%$ of the pancreatectomized rats, gastrin treatment not only increased $\beta$ cells neogenesis from ductal cells but also caused both a modest increase in replication and a decrease in apoptosis in $\beta$ cells with the resultant improvement of glucose tolerance. ${ }^{12}$

Zollinger and Ellison's description of peptic ulcer disease attributable to purported gastrinoma included one case where "the pancreatic tissue removed with the tumor showed normal islands with many large beta -cells...". ${ }^{15}$

Examination of another case with resected pancreas adjacent to an antral gastrinoma "showed a marked proliferation of ducts and islet tissue" with "development of islets from cells (nesidioblasts) within the duct epithelium. $^{14}$

More recently, Meiere et al showed that in cases of intrapancreatic gastrinoma, there was an increase in fractional beta-cell area and cell replication in pancreatic tissue adjacent to but not distant from gastrin-producing tumors, suggesting that either an extremely elevated level of gastrin acting in a paracrine fashion or some other growth factor released by the tumor is required for such trophic cell effects in humans. ${ }^{16}$

\section{CORRELATION OF PROTON PUMP INHIBITOR AND GASTRIN}

Proton pump inhibitors (PPIs) block the parietal cell $\mathrm{H}^{+} / \mathrm{K}^{+}$ATPase, are superior at suppressing acid secretion $\&$ promoting peptic ulcer healing, wildly used clinically for the therapy of gastro-esophageal reflex disease, gastritis due to excess stomach acid, and gastric ulcers. ${ }^{17}$

Gastric acid is a physiologic regulator of gastrin secretion. After blocking the production of gastric acid, the proton-pump inhibitors indirectly elevate serum gastrin levels via a negative feedback effect. ${ }^{14}$

Research results showed that there is a dosage and time dependent relationship between PPIs and gastrin level. ${ }^{3}$

Interestingly, in type 2 diabetes mellitus (T2DM) animal models, it has been reported that PPIs improved glycemic control, probably via possible effects on augmenting both serum levels of gastrin and $\beta$ cell mass. ${ }^{18}$

Although some clinical studies showed negative results on glycemic control by PPIs in patients with T2DM, most studies have demonstrated a significant improvement of glycemic control by PPI administration to these 
patients. ${ }^{19}$ Therefore, these agents appear to have the possibility of being a new approach for the therapy of diabetes. ${ }^{20-23}$

Thus, the hypothesis that proton pump inhibitors can be used to treat type 2 diabetes. The postulated mechanism for this effect is PPI causing endogenous hypergastrinemia which enhances pancreatic $\beta$ cell regeneration and function, and stimulates glucose and amino acid induced insulin secretion. ${ }^{2}$

\section{RESULTS}

\section{Clinical studies for effect of PPI on glycemic control}

Despite the possible effects of gastrin on both increasing $\beta$ cell mass and improving glycemic control, gastrin treatment has not been used with the patients with T2DM mainly because of the difficulty with oral administration and the suggested side effects on the stomach. On the other hand, there are many publications describing the effects of PPIs on glycemic control in patients withT2DM.

Hove et al investigated the effect of esomeprazole on glycemic control in 41 T2DM patients using either dietary control or treatment with oral anti-diabetic agents in randomized double-blind prospective placebocontrolled $2 * 2$ factorial study. ${ }^{19}$ These patients were randomly assigned to take either add-on esomeprazole (40 mg daily, $n=20)$ or placebo $(n=21)$ during $12 \mathrm{wk}$. In the esomeprazole group, the AUC (area under the curve) for insulin did not change, while the AUC for the placebo group significantly decreased. Esomeprazole treatment caused a nine-fold elevation in the AUC for gastrin. Contrary to the expectation, $\mathrm{HbA} 1 \mathrm{c}$ increased from $7.0 \% \pm 0.6 \%$ to $7.3 \% \pm 0.8 \%(\mathrm{P}<0.05)$ in the esomeprazole group and from $7.0 \% \pm 0.6 \%$ to $7.4 \% \pm 0.8 \%$ ( $\mathrm{P}<0.05)$ in the placebo group with no significant difference in change between both treatments.

Similarly, Boj-Carceller et al reported that HbA1c was significantly different in T2DM patients who received PPIs $(6.7 \% \pm 1.0 \%, \mathrm{n}=54)$ compared with those who did not received PPIs $(7.3 \% \pm 1.4 \%, \mathrm{n}=43, \mathrm{P}=0.018) .{ }^{20}$ When these patients were assigned to two groups by the treatment of diabetes, those taking insulin and concurrent PPIs had better glycemic control, compared with those taking insulin but not PPI $(-0.8 \%$ reduction, $\mathrm{P}=0.022)$.

In a very recent study, Barchetta et al, showed that the significantly different HbA1c and FPG levels were found in the T2DM patients with PPIs for longer than 2 years ( $\mathrm{n}$ = 245) compared with those who did not take PPIs ( $\mathrm{n}=$ $303)(7.1 \% \pm 1.07 \%$ with PPIs vs $7.4 \% \pm 1.4 \%$ without PPIs for $\mathrm{HbA} 1 \mathrm{c}, \mathrm{P}=0.011 ; 127 \pm 36.9 \mathrm{mg} / \mathrm{dL}$ with PPIs vs $147.6 \pm 49.6 \mathrm{mg} / \mathrm{dL}$ without PPIs for FPG, P $<0.001$, respectively). ${ }^{21}$ The increase of the differences was observed in patients treated with insulin and in those treated with combination of PPIs and GLP-1 based therapy. The results of these cross-sectional studies suggest the significant association between treatment with PPIs and the improved glycemic control in patients with T2DM.

Crouch et al investigated 71 individuals with T2DM who were not taking insulin. ${ }^{22}$ The mean HbA1c was $7.11 \%$ during periods taking either prescription or over-thecounter (OTC) PPIs, vs $7.71 \%$ during periods not taking PPIs (a significant difference, $\mathrm{P}=0.001$ ). Although there was no significant difference in mean $\mathrm{HbAlc}$ in a metformin monotherapy (6.80 treated with PPIs vs $7.10 \%$ treated without PPIs, $\mathrm{P}=0.25)$, mean $\mathrm{HbA1c}$ was significantly lower inpatients receiving combination therapy including metformin and/or sulfonylurea and/or glitazone (7.26 treated with PPIs vs 7.80 treated without PPIs, $\mathrm{n}=27, \mathrm{P}=0.002$ ).

Furthermore, recent prospective randomized, doubleblind, placebo-controlled studies using PPIs in small number of T2DM patients showed conflicting results with its effect on glycemic control.

Singh et al investigated the effect of a 12-wk pantoprazole (a PPI) therapy regimen on glycemic control in patients with $\mathrm{T}_{2} \mathrm{DM} .^{23}$ Thirtyone eligible patients were randomly assigned to take either pantoprazole $(n=16)$ or placebo $(n=15)$. Pantoprazole (40 mg twice daily) significantly increased both plasma levels of gastrin $(54.4 \pm 14.9$ to $75.6 \pm 15.1 \mathrm{pg} / \mathrm{mL}, \quad \mathrm{P}$ $<0.001)$ and those of insulin $(10.5 \pm 4.0$ to $13.9 \pm 4.5$ $\mu \mathrm{U} / \mathrm{mL}, \mathrm{P}<0.001)$ and improved the function of $\beta$ cell as calculated by the homeostasis model assessment- $\beta$ (HOMA- $\beta$ ). HbA1c significantly decreased with pantoprazole therapy $(7.90 \% \pm 1.17 \%$ to $6.80 \% \pm 1.16 \%, \mathrm{P}$ $<0.001)$. The decrease of $\mathrm{HbAlc}$ was positively associated with a significant elevation in both gastrin and insulin levels.

\section{OTHER POSSIBLE MECHANISMS OF GASTRIN IN REDUCING BLOOD SUGAR LEVEL}

Other than the increase in $\beta$ cell mass, some other mechanisms are also possible.

Gastrin has long been considered a candidate incretin hormone, i.e. an enteral factor responsible for the more than 2-fold increase in insulin secretion when glucose is ingested orally than when administered IV to match peripheral glucose levels. In healthy humans, acute administration of gastrin to achieve supraphysiological levels leads to a modest release of insulin under basal glucose conditions and a more pronounced potentiation of insulin release when co-administered with glucose, evidence supporting an incretin role for gastrin. In physiologic concentrations, gastrin potentiates the glucose-stimulated insulin secretion (during and after a meal) and has minimal effect on basal insulin secretion \& this may partially explain the effect of PPIs on glycemic control. $^{2,13}$ 
Another mechanism may involve the interaction of gastrin with other gastric hormones, such as ghrelin, which is reported to have an important role in energy homeostasis and appetite regulation. There is a report showing that ghrelin was down-regulated in primary gastric cells during gastrin-stimulation, and that ghrelin and gastrin levels had a significant negative correlation in humans. For example, a long-term 3-fold increase of gastrin in autoimmune gastritis significantly repressed ghrelin secretion. These findings might be suggesting the possibility that the increase of gastrin levels is associated with less appetite and improvement of glycemic control via the decreased ghrelin levels. ${ }^{24}$

It is known that the CCK-B receptor exists in the brain, especially in the hypothalamic area. Intracerebroventricular injection of gastrin decreases food intake, while inactivation of CCK-B receptor in mice changes the regulation of food-intake and body weight, and results in obesity. ${ }^{25}$

\section{CONCLUSION}

Although PPI therapy is attractive as a new approach for the therapy of diabetes (especially T2DM), the clinical effect and mechanisms of the clinical effect of PPIs on glycemic control of this drug needs more detailed scientific preclinical and clinical research.

At present concerns are:

- Can we use PPI as main antidiabetic therapy or as an adjunctive therapy?

- What will be duration of treatment?

- As it is stimulating neogenesis of beta cells, will newly formed beta cell mass can continue insulin production for life time? If it is so can we discontinue PPI after a specific duration?

A prospective, long term, randomized, double-blind, placebo-controlled study on PPIs in a larger number of the T2DM patients is warranted to potential efficacy of PPIs on glycemic control, especially in patients with relatively poor glycemic control. If the treatment is for a long-term period, it is also important to consider the possible harmful effects of PPIs, including bone fracture and small intestine bacterial overgrowth. ${ }^{26,27}$

Funding: No funding sources

Conflict of interest: None declared

Ethical approval: Not required

\section{REFERENCES}

1. Tamaki M, Fujitani $Y$, Uchida $T$, Hirose $T$, Kawamori R, Watada H. Combination treatment of $\mathrm{db} / \mathrm{db}$ mice with exendin- 4 and gastrin preserves $\beta$ cell mass by stimulating $\beta$-cell growth and differentiation. Journal of Diabetes Investigation. 2010 October;1(5):172-83.
2. Ashwini V, Suresha RN, Sushma VN, Pushpa VH, Yashoda C, Pragathi B. The Effect of Pantoprazole On Oral Glucose Induced Glycaemic Changes In Normal Albino Rats. International Journal of Pharma and Bio Science. 2012 July;3(3):516-25.

3. Najafipour F, Omidvar M, Reshadatjoo M. Effects of Pantoprazole on Serum Glucose Level in type two diabetic patients. International journal of current research and academic review. 2015 August;3(8):427-36.

4. Takebayashi K, Terasawa T, Naruse R, Hara K, Suetsugu M, Tsuchiya $\mathrm{T}$, et al. Long Term Evaluation of Glycemic Control in Patients with Type 2 Diabetes Receiving Either Alogliptin and Lansoprazole or Alogliptin Mono-therapy for 3 Months Followed by Alogliptin Mono-therapy : A Retrospective Analysis. Dokkyo Journal of Medical Sciences. 2015;42(3):117-25.

5. Burkitt MD, Varro A, Pritchard DM. Importance of gastrin in the pathogenesis and treatment of gastric tumors. World J Gastroenterol. 2009;151-16.

6. Hansen $\mathrm{OH}$, Pedersen $\mathrm{T}$, Larsen JK, Rehfeld JF. Effect of gastrin on gastric mucosal proliferation in man. Gut. 1976;17:536-41.

7. Schubert ML, Makhlouf GM. Neural, hormonal, and paracrine regulation of gastrin and acid secretion. Yale J Biol Med. 1992;65:553-60.

8. Dufresne M, Seva C, Fourmy D. Cholecystokinin and gastrin receptors. Physiol Rev. 2006;86:805-47.

9. Bitziou E, Patel BA. Simultaneous detection of gastric acid and histamine release to unravel the regulation of acid secretion from the guinea pig stomach. Am J Physiol Gastrointest Liver Physiol. 2012;303:G396-403.

10. Saillan-Barreau C, Dufresne M, Clerc P, Sanchez D, Corominola $\mathrm{H}$, Moriscot $\mathrm{C}$, et al. Evidence for a functional role of the cholecystokinin-B/gastrin receptor in the human fetal and adult pancreas. Diabetes. 1999;48:2015-21.

11. Rooman I, Lardon J, Bouwens L. Gastrin stimulates beta-cell neogenesis and increases islet mass from transdifferentiated but not from normal exocrine pancreas tissue. Diabetes. 2002;51:686-690.

12. Téllez N, Joa NNYG, Escoriza J, Vilaseca M, Montanya E. Gastrin treatment stimulates $\beta$-cell regeneration and improves glucose tolerance in $95 \%$ pancreatectomized rats. Endocrinology 2011;152:2580-8.

13. Rehfeld JF, Stadil F. The effect of gastrin on basaland glucose stimulated insulin secretion in man. $\mathrm{J}$ Clin Invest. 1973;52:1415-26.

14. Rickels M, Elahi D. Raising Serum Gastrin to Improve Glycemic Control in (Type 2) Diabetes: Another Limb of the Enteroinsular Axis? J Clin Endocrinol Metab. 2012;97(11):3915-6,

15. Zollinger RM, Ellison EH. Primary peptic ulcerations of the jejunum associated with islet cell tumors of the pancreas. Ann Surg, 1955;142:709-28.

16. Meier JJ, Butler AE, Galasso R, Rizza RA, Butler PC. Increased islet -cell replication adjacent to 
intrapancreatic gastrinomas in humans. Diabetologia. 2006;49:2689-96.

17. Zhang JX, Ji MY, Song J, Lei HB, Qiu S, Wang J, et al. Proton pump inhibitor for non-erosive reflux disease: a meta-analysis. World J Gastroenterol. 2013;19:8408-19.

18. Bödvarsdóttir TB, Hove KD, Gotfredsen CF, Pridal L, Vaag A, Karlsen AE, et al. Treatment with a proton pump inhibitor improves glycaemic control in Psammomys obesus, a model of type 2 diabetes. Diabetologia. 2010;53:2220-3.

19. Hove KD, Brøns C, Færch K, Lund SS, Petersen JS, Karlsen AE, et al. Effects of 12 weeks' treatment with a proton pump inhibitor on insulin secretion, glucose metabolism and markers of cardiovascular risk in patients with type 2 diabetes: a randomised doubleblind prospective placebo-controlled study. Diabetologia. 2013;56:22-30.

20. Boj-Carceller D, Bocos-Terraz P, Moreno-Vernis M, Sanz-Paris A, Trincado-Aznar P, Albero-Gamboa R. Are proton pump inhibitors a new antidiabetic drug? A cross sectional study. World J Diabetes. 2011;2:217-20.

21. Barchetta I, Guglielmi C, Bertoccini L, Calella D, Manfrini S, Secchi C, et al. Therapy with proton pump inhibitors in patients with type 2 diabetes is independently associated with improved glycometabolic control. Acta Diabetol; 2015.

22. Crouch MA, Mefford IN, Wade EU. Proton pump inhibitor therapy associated with lower glycosylated hemoglobin levels in type 2 diabetes. J Am Board Fam Med. 2012;25:50-4.

23. Singh PK, Hota D, Dutta P, Sachdeva N, Chakrabarti A, Srinivasan A, et al. Pantoprazole improves glycemic control in type 2 diabetes: a randomized, double-blind, placebo-controlled trial. J Clin Endocrinol Metab. 2012;97:E2105-8.

24. Rau TT, Sonst A, Rogler A, Burnat G, Neumann H, Oeckl K, et al. Gastrin mediated down regulation of ghrelin and its pathophysiological role in atrophic gastritis. J Physiol Pharmacol. 2013;64:719-25.

25. Clerc P, Coll Constans MG, Lulka H, Broussaud S, Guigné C, Leung-Theung-Long $S$, et al. Involvement of cholecystokinin 2 receptor in food intake regulation: hyperphagia and increased fat deposition in cholecystokinin 2 receptor-deficient mice. Endocrinology. 2007;148:1039-49.

26. Eom CS, Park SM, Myung SK, Yun JM, Ahn JS. Use of Acid-Suppressive Drugs and Risk of Fracture: A Meta-analysis of Observational Studies. Annals of Family Medicine. 2011;9:257-67.

27. Lo WK, Chan WW. Proton pump inhibitor use and the risk of small intestinal bacterial overgrowth: a meta-analysis. Clin Gastroenterol Hepatol. 2013;11:483-90.

Cite this article as: Patil AP, Shirure PA. Effect of add-on proton pump inhibitors on parameters of glycemic control in type-2 diabetic patients. Int $\mathbf{J}$ Basic Clin Pharmacol 2017;6:1233-7. 